The same builder, after flouting the orders of the Supreme Court in the matter of removal of debris and restoration of the original bund, filed a petition challenging the action of the Collector (an Officer of the Indian Administrative Service) who had seized his bank accounts and recovered INR 1.25 crores as dues to be paid to the contractor who had removed the debris. The High Court rejected the builder's pleas and passed strictures against him.

The filing of the case for the protection of mangroves has led to $>5,800$ ha of mangrove areas in Mumbai, Navi Mumbai and Thane being notified as Protected Forests. These areas have been handed over to the Forest Department. The efforts and advocacy of the Conservation Action Trust have led to a special Mangroves Cell being created within the Forest Department. This Cell is headed by an officer of Chief Conservator of Forests rank.

ShweTA BHATT Conservation Action Trust, Mumbai, India E-mailshweta@cat.org.in

\section{China's role in trade in ivory and elephant parts from Lao PDR}

Historically known as the Land of a Million Elephants, the wild Asian elephants Elephas maximus of the Lao People's Democratic Republic remain widely but patchily distributed throughout the country. There is limited information on the trade in ivory or elephant parts in the country but, strategically situated between the world's largest ivory traders, Thailand and China, the trade may be substantial. Economic ties with Thailand have traditionally been strong but in recent years Chinese economic investments in Lao have boomed and, after Thailand, China is now Lao's second largest trading partner. China, Thailand and Lao are all signatories to CITES and no international trade in elephants, their parts or their ivory is permitted. Within Thailand domestic trade in ivory obtained from domestic elephants is permitted and, under tight controls, domestic trade in labelled and registered African ivory is allowed in China. In neither country is trade in elephant parts other than ivory permitted. In Lao elephants are protected and trade in elephants, their parts or ivory is illegal; however, in general, wildlife laws are poorly enforced. Thailand's wild elephant population numbers in the thousands, and that of Lao possibly up to a thousand, but in China only a few hundred wild elephants remain. Taken together this may suggest an emerging role for Lao in the trade in ivory and elephant parts, both domestically and cross-border to China.

We have conducted a series of surveys of wildlife trade in Lao's capital Vientiane, just across the border with Thailand, most recently in August 2011. In the late 1990s to early 2000 s most ivory or elephant parts were traded in the Morning
Market (Telaat Sao) and a series of stalls opposite the nearby central post office. Here, during a 1-day survey in May 1999, Nooren \& Claridge (End of the Game, 2001, IUCN Amsterdam) observed 57 molar pieces, three pieces of skin, one tail, and an unquantified amount of elephant bone for sale. No ivory was recorded. In November 2002 one of us (CRS) observed 101 pieces of carved ivory and four raw tusks or tusk tips, and a few small pieces of elephant skin. Most observations were made at the Morning Market but also at one luxury hotel, and the main clientèle appeared to be either local Laotians or visitors from Thailand (the latter apparently only interested in ivory, not other elephant parts). In August 2011 we observed 12 molar pieces and 15 pieces of elephant skin offered for sale in 22 separate shops or stalls. A total of 2,379 pieces of carved ivory and 12 raw tusks or tusk tips were observed, openly displayed for sale. The trade in elephant parts, used largely for traditional medicine, was still concentrated in the Morning Market. The vendors were all Laotian and prices were in LAK; Laotians and Chinese were the main buyers. The trade in ivory had clearly shifted to antique shops, souvenir shops, jewellery and gem parlours and the lobbies of luxury hotels. The largest quantities of ivory, and the heaviest carved pieces, were displayed in two major luxury hotels, targeting high-end customers.

The main ivory traders and the main clientèle were Chinese (either Chinese nationals or Laotians of Chinese decent). Figurines with Maitreya and Kwan Yin as subjects (representing generosity, compassion and mercy in a Chinese cultural context) suggest that vendors were targeting Chinese customers. Name seals (hanko) observed for sale are exclusively produced for East Asian markets, further suggesting a northwards flow of ivory. Price tags showed prices in CNY or USD (not in LAK), placards were written in Chinese characters, and conversations between vendors and buyers took place in Chinese. Apart from one vendor hiding a large tusk upon our arrival in the shop, all trade in ivory and elephant parts was open, and vendors were generally keen to show their merchandise and discuss details. We were informed by several vendors that the ivory for sale originated from Laotian elephants (with some of the more intricate carving done in Vietnam or China) but we had no way of verifying this.

To the best of our knowledge no regular monitoring of the ivory trade is conducted by the country's law enforcement agencies, and Lao has never reported any seizures of ivory to the Elephant Trade Information System of CITES. The openness of the trade and the willingness of the vendors to talk about the trade attests to insufficient enforcement efforts. It is clear from our surveys that regular monitoring of the markets in Vientiane, including luxury hotels, is needed. Offenders should be prosecuted to the full extent of the law, reflecting the seriousness of the crime and to serve as a strong deterrent. International cooperation in 
this is essential and we urge Lao's CITES, customs and police authorities to work closely with enforcement officers in neighbouring countries and especially in China.

VINCENT NIJMAN Oxford Wildlife Trade Research Group, Department of Anthropology and Geography, Oxford Brookes University, Oxford, OX3 OBP, UK

E-mailvnijman@brookes.ac.uk

Chris R. Shepherd TRAFFIC South-East Asia, Petaling Jaya, Malaysia

\section{International trophy hunting in China}

On 5 August 2011 the national wildlife management authority in the State Forestry Administration of China held an expert consultative meeting on the issue of whether or not to permit the hunting of seven Tibetan gazelles Procapra picticaudata and blue sheep Pseudois nayaur by international trophy hunters in the Dulan International Hunting Ground, Qinghai Province. The applications were submitted by two travel agencies in Beijing on behalf of foreign clients. The consultative meeting, which was opened to the media, was an attempt to reopen international trophy hunting in China following 5 years of suspension. The meeting voted to recommend the reopening of trophy hunting. This news, aired on television, websites and newspapers, stimulated a heated debate about international trophy hunting.

The Qinghai-Tibetan Plateau is home to many endemic species. Before the wildlife protection law was implemented in 1989 many wild animals were hunted on the Plateau: 1.5 million wild animal skins, 271,742 wildfowl and 2.6 million t of game meat were sold between 1965 and 1975. A further 2.9 million wild animal skins, 60,559 wildfowl and 2.1 million t of game meat entered domestic markets from 1976 to 1985 . Hunting was banned nationwide and all sporting firearms were required to be surrendered to the police in 1994. Thus, at present there is no legal hunting permitted in China except in a few approved hunting grounds where artificially bred hare, pheasants and deer are released for recreational hunting. However, international trophy hunting had previously been permitted because hunters harvested a limited number of wild animals and paid a high trophy fee. For example, in the early 1980 s it cost USD 45 to hunt a blue sheep as game meat for sale on the international market but the fee paid by a foreign hunter to hunt a blue sheep as a trophy animal was USD 5,900, plus service and conservation fees. Trophy hunting resulted in reduced hunting pressure on ungulates inhabiting the Plateau while simultaneously generating funds for conservation management and pasture compensation for indigenous herdsmen. Furthermore, herdsmen began to care about the blue sheep because their value to international trophy hunters translated into revenue for the local economy.

Opinion was sharply divided in the debate about the reopening of trophy hunting. Those in favour argued that hunting is widely practised internationally as a management tool to regulate wild animal populations and as a mechanism to generate revenue that is channelled back into local economies and resource management. Principles of conservation and sustainable use of wild animal resources are embodied in CITES and national laws. Experience of trophy hunting in Australia, North America, southern Africa and Mongolia has demonstrated that trophy hunting can achieve successful protection of wild animals and their habitats, create an effective funding base for conservation management, improve local livelihoods and stimulate participation of indigenous peoples.

On the other hand those against were ideologically opposed to any animal being killed for any reason. This group of people formed an alliance to oppose the reopening of trophy hunting. In wide discussion on the internet it was clear that many people either did not believe the results of recent censuses in Dulan International Hunting Ground, which indicate that the populations of blue sheep and Tibetan gazelle are rebounding, or were sceptical that funds generated from trophy hunting would be allocated for conservation.

In the event, however, on 5 September 2011 the two travel agencies in Beijing withdrew their trophy hunting applications to the State Forestry Administration because 'their foreign clients could not make the trophy hunting trip within the time constraints'. Thus trophy hunting in China remains banned.

ZhigANG JiANG and CHUNWANG LI Key Laboratory of Animal Ecology and Conservation Biology, Institute of Zoology, Chinese Academy of Sciences, Beijing, China 100101

E-mail jiangzg@ioz.ac.cn

ROBERT W.G. JENKINS Creative Conservation Solutions, Belconnen Australian Capital Territory, Australia

JIE ZHENG Wild Animal Conservation Bureau, Qinghai Province, Xining, China

\section{3th Conservation Workshop for the Biodiversity of Arabia}

The 13th Annual Conservation Workshop for the Biodiversity of Arabia was held at the Breeding Centre for Endangered Arabian Wildlife (BCEAW) in Sharjah, UAE, on 7-9 February 2012. This regional forum brought together 106 participants representing UAE, Jordan, Saudi Arabia, Bahrain, Kuwait, Egypt, Yemen and Oman, and from the USA, UK, South Africa, Zambia, Germany, Italy and 